\title{
The many facets of the Russian probe
}

\author{
G. O. Yarygin \\ St. Petersburg State University, \\ 7-9, Universitetskaya nab., St. Petersburg, 199034, Russian Federation
}

For citation: Yarygin G. O. The many facets of the Russian probe. Vestnik of Saint Petersburg University. International Relations, 2019, vol. 12, issue 4, pp. 450-464.

https://doi.org/10.21638/11701/spbu06.2019.404

This article presents an analysis of the Russian probe of 2016-2019. The author defines the Russian probe as a complex of investigations originated at different chronological stages by various institutions and communities with regard to Russian meddling in US domestic processes. Distinctive facets of the Russian probe and the varied nature of claims and allegations are reviewed. The author, constituting a two dimensional binary matrix, offers a classification of Russian inquiries based on the chronological characteristics and essence of the case as well as chronology of initiation and institution in charge. The author puts forward and supports a hypothesis stating that the Russian probe is an independent variable of the US political agenda and should not be considered as a byproduct of internal political struggle. The mere personality of the new president, political elite's rejection of Donald Trump, his Russian contacts, and potential predisposition to Russia does not necessarily stipulate initiation of the Russian probe. The author raises and responds to a set of research questions which include but are not limited to: a) does the Russian probe have an electoral dimension only? b) does it have a pure anti-Trump nature? c) was the Russian probe launched following the US presidential election and ignited by the elections? d) does it have a homogenous institutional architecture? Which means of investigations were initiated and conducted by the same institution or did they have a multi-institutional origin? e) if outcomes of varied investigations do not concur, do they have anything in common? And finally, f) will the Russian probe eliminate all risks and threats of the nature under consideration to the USA? The author comes to a conclusion about the inevitability of the Russian probe no matter which candidate would have won the presidency in 2016 and confirms the inability of investigation results to cope with risks of compromising domestic processes.

Keywords: Russia, USA, Russian investigations, meddling, elections, energy, environment.

\section{Framing the research}

The Russian probe has become one of the most powerful factors in the development of American politics under the Donald Trump administration. Recently this factor has been leading inter- and intra- agencies counteraction in the United States, frequently generating such products as arrests, resignations, indictments and sanctions.

Russian probe is an investigation into Russian interference in the domestic processes of the USA. Russian probe is most commonly referred to the Federal Bureau of Investigations examining potential Russian interference in the 2016 election of the United States president and probable collusion of Donald Tramp staff or any individuals associated with his campaign and representatives of the Russian government. For these ends the Depart-

(C) Санкт-Петербургский государственный университет, 2019 
ment of Justice summoned Robert Mueller and appointed him to the position of Special Counsel to deal with the investigation. This investigation was launched on May 17, 2017 and officially concluded on March 22, 2019.

In the broader sense Russian probe refers to all investigations into ties between Russia and the US domestic processes conducted by law enforcement and intelligence agencies, Senate and House of Representatives lawmakers. Special attention of investigations was focused on ties of Russian government and Donald Trump's campaign associates during election campaign and after. However this was not the only sphere where American intelligence, counterintelligence and lawmakers community have been hunting for Russian trail. Besides the elections domain energy, environmental, immigration spheres turned to be compromised. Analysts, attorneys, journalists and scholars have approached them, but those spheres got less politicized, did not involve prominent figures or high profile politicians. That is why those domains did not attract as much attention of mass media as electoral one did.

The author suggests the following hypothesis: Russian probe is an independent variable of the US political agenda and should not be considered as a byproduct of internal political struggle. The mere personality of the new president, political elite rejection of Donald Trump, his Russian contacts and potential predisposition to Russia does not necessarily assume initiation of the Russian probe. Politicization of the probe prevents it from effectively dealing with risks of meddling into the US domestic processes.

To prove the hypothesis the author deals with a set of research questions:

RQ 1: Does Russian probe have the electoral dimension only?

RQ 2: Does Russian probe have an anti-Trump nature?

RQ 3: If Russian probe has been lunched following the US presidential election and ignited by the elections?

RQ 4: Does it have homogenous institutional architecture?

RQ 5: If outcomes of varied investigations do not concur, do they have anything in common? USA?

RQ 6: Will the Russian probe eliminate all risks and threats of the same nature to the

\section{Methodology}

Congressional inquiries and special services' investigations have been grouped into clusters based on the moment of initiation and nature of the probe. Thus a binary matrix has been constructed. The US Presidential election of November 2016 has been defined as a watershed. In other words the results of the elections making Donald Trump the president of the United States, the very fact of which turned to become a conflictual extremum, driving force dividing political elite and American society has been chosen as a crucial point fueling Russian probe. Thus the first two clusters has been formed based on the chronological approach: the first one grouped all enquiries with regard to probable Russian meddling in the US domestic processes announced and launched before the election of November 8 of 2016 and the second group of enquiries originated in the aftermath. After that two sub-clusters have been built in each of them on the basis of the essence of the investigation, on the specificity of nature of the inquiry: the first - if the enquiry re- 
lated to elections and the second - if it related to other matters such as the environment, climate change, energy, race, immigration etc.

Special attention has been devoted to cases selected from the same class characterized by same time span: after Donald Trump was elected as the President, having different essence of examination, originating institution, funding, results and completed by present moment. Thus among all the US Department of Justice Special Counsel investigation and the US House of Representatives Committee on Science, Space and Technology enquiry have been scrutinized in details.

Two dimensional classification of Russian investigations according to binary attributes

\begin{tabular}{|c|c|c|}
\hline & Inquiry relates to electoral agenda & $\begin{array}{c}\text { Inquiry relates } \\
\text { to non-electoral agenda }\end{array}$ \\
\hline $\begin{array}{l}\text { Inquiry originated } \\
\text { before Presidential } \\
\text { elections of } 2016\end{array}$ & FBI launched investigation on July 25, 2016 & \\
\hline $\begin{array}{l}\text { Inquiry originated } \\
\text { after Presidential } \\
\text { elections of } 2016\end{array}$ & $\begin{array}{l}\text { 1) the Department of Homeland Security and } \\
\text { FBI investigation completed on December } \\
29,2016 \text { with the follow up alerts. } \\
\text { 2) Office of the director of the national intel- } \\
\text { ligence report on the results of investiga- } \\
\text { tions by CIA, NSA and FBI (December 9, } \\
2016 \text { - January 6, 2017). } \\
\text { 3) Senate Select Committee on Intelligence } \\
\text { launches investigation (January 13, } \\
2017 \text { - July 3, 2018). } \\
\text { 4) The House Permanent Select Committee } \\
\text { on Intelligence investigation (January 25, } \\
\text { 2017 - March 12/13, 2018). } \\
\text { 5) Special counsel investigation by Special } \\
\text { counsel office (May 17, 2017 - March 22, } \\
\text { 2019). }\end{array}$ & $\begin{array}{l}\text { the US House of Representa- } \\
\text { tives Committee on Science, } \\
\text { Space and Technology in- } \\
\text { vestigation (June 29, } 2017 \text { - } \\
\text { March 1,2018). }\end{array}$ \\
\hline
\end{tabular}

\section{The Variety of Inquests and Characteristics}

\section{Federal Bureau of Investigations probe}

The first round of examination regarding cyber interference into election process was launched by the counterintelligence community. It was not public oriented and its results were not politically motivated. The investigation was launched after Democratic National Convention computers had been compromised. Already on July 25, 2016 the FBI initiates an investigation on possible connection of Russian government and Donald Trump presidential campaign officials. Afterwards this inquiry will be referred as the FBI investigation of the Russian government's efforts to interfere with the 2016 presidential election and related matters. The findings of the investigation were submitted to the thenPresident Barack Obama. Authors of the report argued that foreign interference into the US domestic processes had occurred and roots of the interference traced to Russia. "On December 9, 2016, then-President Barack Obama directed the Intelligence Community to 
conduct a full review and produce a comprehensive intelligence report assessing Russian activities and intentions in recent US elections" [1]. The results of this round of investigation concurred with the previous ones. So enraged was then President Obama with the findings that the decision was taken to make them available to Congressional leadership and the president-elect Donald Trump before the inauguration.

\section{Federal Bureau of Investigations and Department of Homeland Security joint efforts}

December 29, 2016 the Department of Homeland Security and FBI released a Joint Analysis Report (the JAR) that expanded on the Obama administration's October 7 statement accusing the Russian government of interfering in the election [2]. The JAR "provide[d] technical details regarding the tools and infrastructure used by the Russian civilian and military intelligence services to compromise and exploit networks and endpoints associated with the US election, as well as a range of US Government, political, and private sector entities" [3].

As part of its day to day activity the Department of Homeland Security (DHS) and the Federal Bureau of Investigation (FBI) take analytical efforts titled alerts "to provide technical details on the tactics, techniques, and procedures used by Russian government cyber actors". The DHS and FBI make the results of their work publicly available "to enable network defenders to identify and reduce exposure to Russian malicious cyber activity, which the US Government refers to as Grizzly Steppe."

Thus since 2016 to present day five joint FBI-DHS alerts by the National Cybersecurity and Communications Integration Center (NCCIC) have been disseminated with regard to Russia:

1. April 16, 2018: Technical Alert: Russian State-Sponsored Cyber Actors Targeting Network Infrastructure Devices [4];

2. March 15, 2018: Technical Alert: Russian Government Cyber Activity Targeting Energy and Other Critical Infrastructure Sectors [5];

3. February 15, 2018: Technical Alert: Petya Ransomware (originally published July $1,2017)[6]$;

4. February 10, 2017: Analysis Report: Enhanced Analysis of GRIZZLY STEPPE Activity [7];

5. December 29, 2016: Joint Analysis Report: GRIZZLY STEPPE - Russian Malicious Cyber Activity [3].

\section{The Office of the director of the national intelligence assessment}

However before the inauguration President-elect Trump's position on Russian interference in the election remained unclear. Possibly Donald Trump was simply too busy with pre-inaugural matters. Responding to the Obama administration's sanctions, President-elect Trump simply stated that the "country [should] . . move on to bigger and better things." He then agreed to meet with intelligence officials so he could "be updated on the facts" of the hacking [8]. On January 6, 2017 Donald Trump was briefed by the intelligence officials and handed over the original, classified version of the report "Background to "Assessing Russian Activities and Intentions in Recent US Elections": The Analytic Process and Cyber Incident Attribution" prepared by the Office of the director of the national intelligence. 
January 6, 2017 - the Office of the director of the national intelligence (ODNI) released a declassified version of its classified report concluding investigation on potential collusion of Russian government and Donald Trump campaign officers. The report had been prepared and provided to the US president and other authorized recipients. It should be noted that under the National Security Act of 1947 as emended in 2004 by the Intelligence reform and terrorism prevention act the Director of the national intelligence is the principal advisor to the president on intelligence. $[9 ; 10]$ The Director is the chief of the intelligence community of the United States which is very diverse. Different bureaus examine foreign influence or interference. That is why initially it was not clear what agencies got involved into investigating Russia concerning the electoral campaign and if they could be biased. After the report was released it came to light that it was coordinated by three key US counterintelligence institutions: The Federal Bureau of Investigation (FBI), The Central Intelligence Agency (CIA) and The National Security Agency (NSA). It is emphasized in the report that it provides an assessment not by one of them or by the Director himself but the assessment is elaborated "by all three agencies" [11]. This fact endorses political impartiality of findings of the report. The report itself states "The US Intelligence Community is charged with monitoring and assessing the intentions, capabilities, and actions of foreign actors; it does not analyze US political processes or US public opinion" [11]. Closing their investigation of 2016 the US Intelligence community presented the assessment of "motivation and scope of Moscow's intentions regarding US elections and Moscow's use of cyber tools and media campaigns to influence US public opinion" concluding that interference took place. The report also concludes: Russia did not break into technical voting process (voting machines and tabulation of votes), but meddled by spreading pro-Trump propaganda. Simultaneously the press release of the web site of the US Senate Select Committee on Intelligence "ODNI Statement on Declassified Intelligence Community Assessment of Russian Activities and Intentions in Recent US Elections" dated January 6, 2017 adds the same assessment of the Department of Homeland Security: "DHS assesses that the types of systems the Russian actors targeted or compromised were not involved in vote tallying" [1]. At the same time the report did not characterize and not qualified the effectiveness of the interference: "We did not make an assessment of the impact that Russian activities had on the outcome of the 2016 election".

In March 2017 James Clapper the Director of National Intelligence appointed by President Obama in 2010 and remaining in office till January 2017 answering question on TV show "Meet the Press" speaking about "our" report once again specified origins of the report emphasizing its versatility and neutrality: "I say, "our" that's N. S. A., F. B. I. and C. I. A."

After the briefing, President-elect Trump released a statement that did not address primarily the report however Donald Trump underlined one of the report's key findings leaving others behind.

"Russia, China, other countries, outside groups and people are consistently trying to break through the cyber infrastructure of our governmental institutions, businesses and organizations including the Democratic National Committee... there was absolutely no effect on the outcome of the election... including the fact that there was no tampering whatsoever with voting machines. There were attempts to hack the Republican National Committee, but the Republican National Committee had strong hacking defenses and the hackers were unsuccessful [12]. 


\section{Senate Select Committee on Intelligence inquiry}

January 13, 2017 the Senate select committee on intelligence initiates Russian probe based on the report of the Office of the director of national intelligence which was aimed at "provid[ing] decision makers with rigorous, objective and relevant assessments based on an appropriate basis for the judgment to clarify uncertainties associated with major challenges" [11].

Senator Richard Burr (Republican - North Carolina), Chairman of the Senate Select Committee on Intelligence and Senator Mark Warner (Democrat - Virginia), Vice Chairman of the Senate Select Committee on Intelligence issued a joint statement launching the inquiry. The intention or rather commitment to investigate Russian interference was announced month before by Senator Mitch McConnell (Republican - Kentucky) on December 12, 2016. McConnell stated that a panel of senators from the Senate Intelligence Committee headed by Senator Richard Burr would pursue a bipartisan investigation of Russia's interference in the election. It was done at the press conference which was nicknamed by the Washington Post "Russians are not our friends" [13].

The Committee's inquiry addressed:

- "A review of the intelligence that informed the Intelligence Community Assessment "Russian Activities and Intentions in Recent US Elections;"

- Counterintelligence concerns related to Russia and the 2016 US election, including any intelligence regarding links between Russia and individuals associated with political campaigns;

- Russian cyber activity and other "active measures" directed against the U.S., both as it regards the 2016 election and more broadly" [14].

July 3, 2018 the Senate Intelligence committee released a report concluding that the intelligence community's January 2017 assessment of election meddling was accurate. Senators accented "those analysts who drafted and prepared the ICA......were under no politically motivated pressure to reach any conclusions...All analysts expressed that they were free to debate, object to content, and assess confidence levels, as is normal and proper for the analytic process... "the analytical disagreement was reasonable, transparent, and openly debated among the agencies and analysts, with analysts, managers, and agency heads on both sides of the confidence level articulately justifying their positions." The latter passage referred to different confidence levels between the CIA, FBI and the National Security Agency with regard whether the Russian government were aspiring to facilitate Trump election: while the NSA claimed with "moderate confidence" the CIA and FBI assessed with "high confidence" "that the goal of the election interference was to help Trump rather than simply create confusion" [15].

\section{The House Permanent Select Committee on Intelligence inquiry}

The US Senate had been momentarily followed by the House Representatives in "overseeing the Intelligence Community's activities to counter Russian aggression, including the cyber-attacks directed against the United States in the last year" [16].

The House Permanent Select Committee on Intelligence Chairman Devin Nunes (Republican - California) and Ranking Member Adam Schiff (Democrat - California) released a statement announcing a bipartisan inquiry that would be aimed at and not limited to: 
- "Russian cyber activity and other "active measures" directed against the US and its allies;

- Counterintelligence concerns related to Russia and the 2016 US election, including any intelligence regarding links between Russia and individuals associated with political campaigns;

- The United States Government response to these Russian active measures and any impact they may have on intelligence relationships and traditional alliances; and

- Possible leaks of classified information related to the Intelligence Community's assessments of these matters" [16].

The idea of the investigation was preliminary backed up by the House of Representatives Speaker Paul D. Ryan (Republican -Wisconsin). The House Permanent Select Committee on Intelligence conducted investigation from January 25, 2017 till March 12, 2018. The Committee proceedings founded on the data of the intelligence community it oversees resulted in two reports of opposite character. On March 12, 2018 a Republican faction of the Committee formally ended Russian investigation and issued a report announcing that there was no collusion between Russian government and individuals associated with Trump political campaign thus concluding that Russia was not facilitating Trump to win elections. The next day, March 13, 2018 a Democratic faction responded with a statement on commitment to continue their efforts and investigation [17].

\section{Special counsel investigation by Special counsel office}

May 17, 2017 - March 22, 2019

On May 17, 2017, Robert S. Mueller III (Former FBI Director) was appointed by acting Attorney General Rod J. Rosenstein to serve as Special Counsel for the United States Department of Justice by the Order № 3915-2017 to investigate Russian interference with the 2016 presidential election and related matters [18].

Special counsel had been authorized:

to investigate any links and/or coordination between the Russian government and individuals associated with the campaign of President Donald Trump;

any matters that arose or may arise directly from the investigation;

any other matters....

Mueller's team included 19 lawyers supported by 40 FBI agents, intelligence analysts, forensic accountants and other professional staff. The group has demonstrated high efficiency. The Special Counsel issued more than 2800 subpoenas, executed nearly 500 search warrants, obtained more than 230 orders for communication records, issued almost 50 orders authorizing use of pen registers, made 13 requests to foreign governments for evidence and interviewed approximately 500 witnesses.

On March 22 (Friday), 2019 - the Special Counsel submitted to the US Attorney General William P.Barr a confidential report explaining the prosecution or declination decisions he has reached. This report was entitled "Report on the Investigation into Russian Interference in the 2016 Presidential Election".

On March 24 (Sunday), 2019 - the US Attorney General William P. Barr sent a letter to Lindsey Graham (Republican - South Carolina) Chairman of the Committee on the Judiciary of the United States Senate, Dianne Feinstein Ranking (Democrat - California) Member of the Committee on the Judiciary of the United States Senate, Jerrold Nadler 
(Democrat - New York), Chairman of the Committee on the Judiciary United States House of Representatives, Doug Collins (Republican - Georgia), Ranking Member of the Committee on the Judiciary of the United States House of Representatives informing them about the status of his initial review and principle conclusions documented in the report. Lawmakers and mass media interpreted the Attorney General letter as a summary of the report heavily criticizing it for being heavily edited. A week later, on March 31, 2019 William P. Barr sent another letter to Congress, stating that his previous letter was inaccurately characterized by as a "summary" of Special Counsel Mueller's report. "My letter was not, and did not purport to be, an exhaustive recounting of the Special Counsel's investigation or report" [19].

On April 18, 2019 a redacted version of the Report On The Investigation Into Russian Interference In The 2016 Presidential Election by Special Counsel Robert S. Mueller is released [20]. The forts pat of the report relates to potential conspiracy crimes. It explains the Special Counsel decisions not to charge individuals associated with the campaign. The second part of the report covers episodes regarding possible obstruction of justice by the president. Nevertheless Special Counsel made a decision not to charge the president. At the same time the report did not rehabilitate Donald Trump.

"If we had confidence after a thorough investigation of the facts that the President clearly did not commit obstruction of justice, we would so state... Based on the facts and the applicable legal standards, however, we are unable to reach that judgment". Thus Robert Mueller clearly did not speak about exoneration.

Despite quite moderate character of the outcomes of the report lawmakers continued enforcing suspicions and charges against the sitting president. On May 1, 2019 Attorney General Barr was questioned by the Senate Judiciary Committee. William Barr echoed Robert Mueller and did not exonerate the President reasoning for declining to pursue an obstruction of justice charge against him. "I said that we did not believe that there was sufficient evidence to establish an obstruction offense which is the job of the Justice Department". Such outcomes of quite long and rather expensive probe did not meet expectations of many, but powered President Trump current positions.

The probe cost more than $32 \mathrm{mln}$ dollars. This accounting embraced both the amount special counsel Robert Mueller borrowed from other Justice Department components that were under his office's direct expenses as well as those which weren't under his direct control. President supporters and he himself criticized "unnecessary spending of taxpayers' dollars." Opponents fended off emphasizing that money forfeited from convicted (e.g. from Paul Manafort) would compensate expenditures. "In the Paul Manafort case alone, you recovered as much as $\$ 42$ million - so that the cost of your investigation to the taxpayers approaches zero." (Mueller testimony: The opening statement from House Judiciary Chairman Jerrold Nadler). In September 2018 Paul Manafort agreed to forfeiture real estate and cash estimated to be worth as much as $\$ 46$ million as part of his plea agreement. Substantia part of what he is turning over goes back to banks to which he owed money, according to his forfeiture court proceedings. Remaining forfeiture goes to the Department of Justice's Assets Forfeiture Fund. According to the Justice Department policy almost 130000 dollars in total fines will go to the Federal fund for crime victims.

As a matter of financial transparency the SCO released four expenditures reports. Usually the report was released each six and a half months. The forth report got published 
in seven and a half months. It was released after Mueller testified before two House committees in Congress.

The Special Counsel's Office (SCO) Statement of Direct and Reimbursed Expenditures

\begin{tabular}{|l|c|c|c|c|}
\hline \multicolumn{1}{|c|}{ Period } & $\begin{array}{c}\text { May 17, 2017- } \\
\text { September 30, } \\
\text { 2017 [21] }\end{array}$ & $\begin{array}{c}\text { October 1, } \\
\text { 2017- March 31, } \\
\text { 2018 [22] }\end{array}$ & $\begin{array}{c}\text { April 1, 2018- } \\
\text { September 30, } \\
\text { 2018 [23] }\end{array}$ & $\begin{array}{c}\text { October 1, } \\
\text { 2018 - May 31, } \\
\text { 2019 [24] }\end{array}$ \\
\hline $\begin{array}{l}\text { Personnel } \\
\text { Compensation and } \\
\text { Benefits }\end{array}$ & $\$ 1,709,597$ & $\$ 2,738,131$ & $2,886,270$ & $2,449,241$ \\
\hline $\begin{array}{l}\text { Travel and } \\
\text { Transportation of } \\
\text { Persons }\end{array}$ & 223,643 & 532,340 & 580,098 & 244,816 \\
\hline $\begin{array}{l}\text { Transportation of } \\
\text { Things }\end{array}$ & 156 & 1,345 & 779 & 229 \\
\hline $\begin{array}{l}\text { Rent, } \\
\text { Communications, and } \\
\text { Utilities }\end{array}$ & 362,550 & 886,403 & 942,787 & 869,335 \\
\hline $\begin{array}{l}\text { Printing and } \\
\text { Reproduction }\end{array}$ & 157,339 & 264,114 & 310,732 & 313,456 \\
\hline $\begin{array}{l}\text { Contractual Services } \\
\text { primarily related to } \\
\text { IT) }\end{array}$ & $3,213,695$ & $4,506,624$ & $4,567,533$ & $4,120,899$ \\
\hline $\begin{array}{l}\text { Supplies and Materials } \\
\text { Acquisition of } \\
\text { Equipment }\end{array}$ & 26,442 & 29,694 & 43,334 & 14,554 \\
\hline $\begin{array}{l}\text { Total SCO } \\
\text { Expenditures }\end{array}$ & 733,969 & 54,597 & $(212,085)$ & 229,268 \\
\hline
\end{tabular}

Most of the fees of the Special Counsel Office have gone to personnel compensation and benefits.

The SCO's Russian probe led to more than 100 criminal charges being filed against Russian companies and individuals, including up to 7 former Trump advisors.

It is worth noting that the United States Department of Justice Special Counsel Office (under different titles such as Special Prosecutor Office later changed to Independent Counsel Office) has been working since 1978. The independent institution has been applied by the US Congress or the US Attorney General to investigate individuals holding high positions in the federal government and any other individuals or matters arising from its investigations. The office's practice commonly captures public attention. Probably till now the most known cases and Special Counsels are The Independent Counsel Lawrence E. Walsh investigation dealing with the Iran-Contra affair and Kenneth Starr's investigation into President Bill Clinton-Lewinsky affair. The report of Kenneth Starr led to the impeachment of Bill Clinton by the United States House of Representatives though it did not succeed in the United States Senate. 


\section{The US House of Representatives Committee on Science, Space and Technology inquiry}

Russian probe of 2016-2019 went far beyond the electoral agenda. It embraced examining potential Russian interference into other spheres of domestic American affairs covering energy, environment, civil and political rights etc. These investigations were predominantly initiated by the lawmakers. Thus on July 7, 2017, Chairman of the US House of Representatives Committee on Science, Space and Technology, Lamar Smith (Republican - Texas) and Energy Subcommittee Chairman Randy Weber (Republican - Texas) sounded the alarm concerning potential Russian interference in the US energy market through covertly funding environmental groups opposed to fossil fuels and fracking technologies. June 29, 2017 Congressmen sent a letter to the US Treasury Secretary Steven Mnuchin strongly advising him to launch investigation of these allegations [25]. The committee's concern was stipulated by its wide jurisdiction over the Department of Energy, the Environmental Protection Agency, the National Science Foundation, NASA, the Federal Aviation Administration and the National Institute of Standards and Technology.

The personality factor also played its role. Representative Lamar Smith is a politically heavyweight congressman. Leading the US House of Representatives Committee on Science, Space and Technology, he was a former Chairman of the Judiciary Committee and the Ethics Committee. This made him the only recent member of the US Congress to have chaired three committees. He also served on the Judiciary Committee and the Homeland Security Committee. Lamar scientific views worth noting: he has firmly questioned climate change concept [26] and backs up fracking projects. However such provocative initiation should not be perceived as a populist move in search of reelection. Other imperatives stood behind Lamar's Russian energy and environment probe. On November 2, 2017 Congressman Smith announced that he would not seek re-election in 2018 [27].

On September 26, 2017 and October 31, 2017 Chairman of the US House of Representatives Committee on Science, Space and Technology sent letters to three tech giants Twitter, Facebook [28] and Alphabet Inc (Google parent company) demanding evidences proving that Russia utilized "social media to influence the US energy market" by purchasing energy and environment related ads of anti-fracking, anti-fossil fuel character on their platforms and provoking discord. That statement mainly related to a controversy between American conservatives who largely back up fracking and progressives who opposed and have protested against it, also to debates over new pipeline projects and rights of indigenous peoples of the United States for their lands [29]. Lamar requested "all documents and communications referring or relating to the source of advertisements" on Alphabet, Facebook or Twitter "affiliated entities advocating for so-called green initiatives". Chairman Smith argued: "Social media platforms, such as Twitter and Facebook, have the ability to serve as an effective propaganda arm conveying specific messages to geographically targeted audiences". His ultimate concern and judgement was finalized as following: "The committee is concerned that divisive social and political messages conveyed through social media have negatively affected certain energy sectors... which can depress research and development in the fossil-fuel sector and the expanding potential for natural gas." Despite the fact that at a time of demanding materials from social media managers Congressman Smith did not provide any evi- 
dences of his allegations, he referred to a 2014 report of The New York Times arguing that Russia stood behind anti-fracking protests in Europe [30].

IT giants cooperated with the Russian probe providing information within legal limits, the tech giants' terms of service and operating procedures. For example a Twitter spokesman commented to journalists on the inquiry confirming that "the company had received the letter and would respond but did not address a question about whether Russian-funded anti-fracking ads would violate the company's advertising policies" [31]. Being under lawmakers' microscope digital trio provided materials requested for the investigation of the US House of Representatives Committee on Science, Space and Technology. Twitter acting general counsel Sean Edgett, Facebook general counsel Colin Stretch and Google law enforcement and information security director Richard Salgado testified in Congress during a US Senate Judiciary Subcommittee on Crime and Terrorism hearing on Russian influence on social networks on Capitol Hill in Washington, DC, October 31, 2017. Afterwards they also submitted answers to Senator's followup questions about Russia's interference in writing. IT giants share general consent on positive and negative potential of Russian digital tools in advancing Russian agenda. Worth noting is that such argumentation is recognized internationally and also shared by Russian scholars [32].

On March 1, 2018 the United States House of Representatives Committee on Science, Space and Technology released a Majority Staff Report "Russian Attempts to Influence US Domestic Energy Markets by Exploiting Social Media" [33]. Key findings of the report endorsed initial argumentation of the lawmakers. The report stated that Russian interference into domestic affairs of the United States embraced various spheres and issues such as but not limited to environment, fossil fuels, climate change, pipelines and other divisive aspects to influence public policy in the US "Russian-sponsored agents funneled money to US environmental organizations in an attempt to portray energy companies in a negative way and disrupt domestic energy markets, suppress research and development of fossilfuels, and stymie efforts to expand the use of natural gas".

The report further specified "Russia exploited American social media as part of its concerted effort to disrupt US energy markets and influence domestic energy policy". For these ends social media were employed by the Internet Research Agency (IRA) - Russian company affiliated to the Russian government and promoting and advancing Russian interests. The authors of the report enhance relevance and credibility to the report allegation by comparing accusatory data on energy and environment with data on elections: "according to information provided by Twitter, more than four percent of all IRA tweets were related to energy or environmental issues, a significant portion of content when compared to the eight percent of IRA tweets that were related to the election in the US."

\section{Conclusions}

The hypothesis put forward in the beginning of the research has been confirmed by answering research questions.

RQ 1: Does Russian probe have the only electoral dimension? Russian probe of 20162019 is a multifaceted phenomenon. Russian probe is an independent variable of the US political agenda. It does not necessarily depend on electoral cycles or political confrontation. Other factors may have their effects: economic, social or individual. Through the 
perspective of this research question the Russian probe cases may be classified as follows: 1) Elections related cases, 2) Non-elections related cases.

RQ 2: Does Russian probe have an anti-Trump nature?

The mere personality of the new president, political elite rejection of Donald Trump, his Russian contacts and potential predisposition to Russia did not necessarily assume initiation of the Russian probe. The electoral dimension of the probe has become the most flagrant and the most covered by mass media intrigue, but not the only one. It has become a trigger factor, but not the core, the essence of the probe. Russian probe has revealed that foreign meddling affected various spheres, issues and domestic processes of the United States including environment, climate change, energy, race, immigration, religious, LGBT issues, gun rights etc. The FBI share of the Russian probe resulted in corruption indictments and conspiracy to obstruct justice charges, but did not refer to President Trump himself. However it did not exonerate him.

RQ 3: If Russian probe has been lunched following the US presidential election and ignited by the elections?

The largest part of Russian investigations relate to the second cluster and the first sub cluster: investigations had been initiated after the election of Donald Trump and related to elections. This aspect makes them vulnerable to criticism of being politically motivated. However certain investigations done by either intelligence or lawmakers' community attribute to pre electoral period and to non-electoral matters.

Through the perspective of this research question the Russian probe cases may be classified as follows: 1) Initiated or inspired before elections, 2) Initiated or inspired after elections and elections related or non-related investigations.

Major part of investigations had been originated after the elections, however based on the information and assessments done before the elections.

RQ 4: Does it have homogenous institutional architecture?

Investigators has practiced different approaches to Russian meddling, inquiries were initiated, conducted and completed by diverse institutions, some probes turned to be very resource consuming, certain inquiries ended up with particular reports while other have remained uncompleted. Investigations were connected often being built on the same special services assessments but not coordinated. Investigating institutions did not affect each other. Different institutions conducting independent investigations applied a large number of instruments such as classified reports, inquiries, hearings, collecting testimonies etc. Through the perspective of this research question the Russian probe cases may be classified as follows: 1) Initiated by intelligence community or 2) Initiated by lawmakers' community.

RQ 5: If outcomes of varied investigations do not concur, do they have anything in common?

Despite a diverse nature of findings (some of them turned to become biased and contradict to each other) investigators have reached a consent on the dramatic change in dissemination of information that the development of social media brought with its progress. On the one hand social media substantially contribute to democratization, progress of civil society and public discourse, on the other had they carry a risk of being compromised, misused and abused. Such a confidence is shared by Russian scholars as well. Investigators also agreed on the detected technique, universalism of the technique and the efficiency of the technic applied to influence domestic American political, economic and 
social processes. Utilization of social media, revealing and targeting visible highly tension points and polarizing them by posting divisive materials, identifying adversary interest communities, messaging and engaging with them on-line has considerable off-line effect and can destabilize various US domestic processes and diverse sectors, paralyze and discredit political on-line and off-line conversation.

\section{USA?}

RQ 6: Will the Russian probe eliminate all risks and threats of the same nature to the

All institutions involved into Russian probe emphasize one way or another that the probe is just an indicator of the permanent and ongoing process. The probe itself is not a firewall. On July 2014, 2019 Special counsel Robert Mueller III testified before the House of Representative Permanent Select Intelligence Committee. He answered affirmatively to the question if foreign groups heaving substantial technological abilities and certain intentions pose a significant threat to the United States and the US allies in upcoming elections and added "many more countries are developing capability to replicate what the Russians had done".

Representative Peter Welch (Democrat - Vermont) went further and raised the issue: "...have we established a new normal from this past campaign that is going to apply to future campaigns, so that if any one of us running for the US House, any candidate for the US Senate, and candidacy for the presidency of the United States, aware that if hostile foreign powers trying to influence an election has no duty to report that to the FBI or their authorities... Robert Mueller pessimistically responded: "I hope this is not the new normal, but I fear it is" [34].

\section{References}

1. ODNI Statement on Declassified Intelligence Community Assessment of Russian Activities and Intentions in Recent US Elections. January 6, 2017. Senate Select Committee on Intelligence, available at: https:// www.intelligence.senate.gov/publications/assessing-russian-activities-and-intentions-recent-us-elections (accessed: 02.03.2017).

2. Joint DHS, ODNI, FBI Statement on Russian Malicious Cyber Activity. December 29, 2016. Department of Homeland Security, available at: https://www.dhs.gov/news/2016/12/29/joint-dhs-odni-fbi-statement-russian-malicious-cyber-activity (accessed: 12.05.2019).

3. Joint Analysis Report: GRIZZLY STEPPE - Russian Malicious Cyber Activity. December 29, 2016. National Cybersecurity and Communications Integration Center (NCCIC), the Department of Homeland Security (DHS) and the Federal Bureau of Investigation (FBI), available at: https://www.us-cert.gov/sites/ default/files/publications/JAR_16-20296A_GRIZZLY\%20STEPPE-2016-1229.pdf (accessed: 12.05.2019).

4. Technical Alert: Russian State-Sponsored Cyber Actors Targeting Network Infrastructure Devices. April 16, 2018. National Cybersecurity and Communications Integration Center (NCCIC), the Department of Homeland Security (DHS) and the Federal Bureau of Investigation (FBI), available at: https://www.us-cert. gov/ncas/alerts/TA18-106A (accessed: 12.05.2019).

5. Technical Alert: Russian Government Cyber Activity Targeting Energy and Other Critical Infrastructure Sectors. March 15, 2018. National Cybersecurity and Communications Integration Center (NCCIC), the Department of Homeland Security (DHS) and the Federal Bureau of Investigation (FBI), available at: https:// www.us-cert.gov/ncas/alerts/TA18-074A (accessed: 12.05.2019).

6. Technical Alert: Petya Ransomware. February 15, 2018. National Cybersecurity and Communications Integration Center (NCCIC), the Department of Homeland Security (DHS) and the Federal Bureau of Investigation (FBI), available at: https://www.us-cert.gov/ncas/alerts/TA17-181A (accessed: 12.05.2019).

7. Analysis Report: Enhanced Analysis of GRIZZLY STEPPE Activity. February 10, 2017. National Cybersecurity and Communications Integration Center (NCCIC), the Department of Homeland Security (DHS) and the Federal Bureau of Investigation (FBI), available at: https://www.us-cert.gov/sites/default/files/publications/AR-17-20045_Enhanced_Analysis_of_GRIZZLY_STEPPE_Activity.pdf (accessed: 12.05.2019). 
8. Shear M. D. (2016), Donald Trump, After Dismissing Hacking, Agrees to an Intelligence Briefing. New York Times, December 29, available at: https:/www.nytimes.com/2016/12/29/us/politics/donald-trumprussia-hack.html (accessed: 19.04.2019).

9. National Security Act of 1947, available at: https://www.dni.gov/index.php/ic-legal-reference-book/ national-security-act-of-1947 (accessed: 24.03.2019).

10. Act To reform the intelligence community and the intelligence and intelligence-related activities of the United States Government (Intelligence Reform and Terrorism Prevention Act) of 2004, available at: https:// www.dni.gov/index.php/who-we-are/organizations/ogc/ogc-related-menus/ogc-related-content/irtpaof-2004 (accessed: 12.05.2019).

11. Background to "Assessing Russian Activities and Intentions in Recent US Elections": The Analytic Process and Cyber Incident Attribution. 6 January, 2017, p. i, available at: https://www.dni.gov/files/documents/ ICA_2017_01.pdf (accessed: 14.05.2019).

12. Donald Trump's Statement After Intelligence Briefing on Hacking. New York Times, January 6, 2017, available at: https://www.nytimes.com/2017/01/06/us/politics/donald-trump-statement-hack-intelligencebriefing.html (accessed: 19.04.2019).

13. O’Keefe, E., Kane, P., Demirjian, K. (2016), McConnell announces Senate probe of suspected Russian election interference: "The Russians are not our friends". The Washington Post, December 12, available at: https://www.washingtonpost.com/news/powerpost/wp/2016/12/12/schumer-on-congressional-probe-ofrussia-i-dont-want-this-to-turn-into-a-benghazi-investigation/ (accessed: 02.03.2019).

14. Joint Statement on Committee Inquiry into Russian Intelligence Activities. By Richard Burr, US Senator for North Carolina. Press Release, January 13, 2017, available at: https://www.burr.senate.gov/press/releases/ joint-statement-on-committee-inquiry-into-russian-intelligence-activities (accessed: 18.05.2019).

15. Senate Intelligence Committee report July 3, 2018, available at: https://www.burr.senate.gov/imo/media/doc/SSCI\%20ICA\%20ASSESSMENT_FINALJULY3.pdf (accessed: 27.03.2018).

16. Joint Statement on Progress of Bipartisan HPSCI Inquiry into Russian Active Measures. Washington, January 25, 2017, available at: https://intelligence.house.gov/news/documentsingle.aspx?DocumentID=211 (accessed: 21.04.2019).

17. House intelligence Democrats outline how to keep their Russia investigation alive Available at: https://edition.cnn.com/2018/03/14/politics/adam-schiff-house-intelligence-democrats/index.html (accessed: 19.04.2019).

18. Order on Appointment of Special Counsel to Investigate Russian Interference with the 2016 Presidential Election and Related Matters № 3915-2017, available at: https://www.justice.gov/opa/press-release/ file/967231/download (accessed: 12.05.2019).

19. Attorney General William Barr's letter to judiciary committee leaders about the release of the Mueller report, available at: https:/edition.cnn.com/2019/03/29/politics/barr-letter-mueller-release/index.html (accessed: 12.05.2019).

20. Report on the Investigation Into Russian Interference in the 2016 Presidential Election. Volume I of II, by Special Counsel Robert S. Mueller, III Submitted Pursuant to 28 C. F.R. \$ 600.8(c), Washington, D.C. March, 2019, available at: https://www.justice.gov/storage/report_volume2.pdf (accessed: 16.06.2019).

21. Special Counsel's Office Statement of Expenditures May 17, 2017 to September 30, 2017. The US Department of Justice, available at: https://www.justice.gov/opa/press-release/file/1015746/download (accessed: 27.03.2019).

22. Special Counsel's Office Statement of Expenditures October 1, 2017 through March 31, 2018. The US Department of Justice, available at: https://www.justice.gov/jmd/page/file/1067411/download (accessed: 27.03.2019).

23. Special Counsel's Office Statement of Expenditures April 1, 2018 through September 30, 2018. The US Department of Justice, available at: https://www.justice.gov/sco/page/file/1120106/download (accessed: 27.03.2019).

24. Special Counsel's Office Statement of Expenditures October 1, 2018 through May 31, 2019. The US Department of Justice, available at: https://www.justice.gov/jmd/page/file/1190286/download (accessed: 27.03.2019).

25. Letter from Hon. Lamar Smith, Chairman, the US House of Representatives Committee on Science, Space and Technology to Hon. Steven T.Mnuchin, Secretary, US Department of Treasury. June 29, 2017, available at: https://republicans-science.house.gov/sites/republicans.science.house.gov/files/documents/06_29_2017 CLS \%26 Weber — Mnuchin.pdf (accessed: 27.03.2019).

26. Hirji, Z. (2017), This Congressman Doesn't Think Climate Science Is Real. He Just Went On A Secret Tour Of The Melting Arctic. BuzzFeedNews, July 14, available at: https://www.buzzfeednews.com/article/ zahrahirji/lamar-smith-tours-the-arctic .io5NmJOqEe (accessed: 27.03.2018). 
27. Dixon, D. (2017), Lamar Smith won't seek reelection to House, 11 February, available at: https://www. politico.com/story/2017/11/02/lamar-smith-wont-seek-reelection-to-house-244477 (accessed: 04.05.2019).

28. Letter from Hon. Lamar Smith, Chairman, the US House of Representatives Committee on Science, Space and Technology to Mr. Mark E. Zuckerberg, Founder, Chairman and Chief Executive Officer, Facebook and Mr. Jack Dorsey, Chief Executive Officer, Twitter, Inc. September 26, 2017.

29. Brooks, R. C. (2017), How Russians Attempted To Use Instagram To Influence Native Americans. BuzzFeedNews, October 27, available at: https://www.buzzfeed.com/amphtml/ryancbrooks/russian-trollefforts-extended-to-standing-rock (accessed: 19.03.2018).

30. Higgins, A. (2014), Russian Money Suspected Behind Fracking Protests. The New York Times, November 30, available at: https://www.nytimes.com/2014/12/01/world/russian-money-suspected-behindfracking-protests.html? mcubz=1\&mtrref=www.google.com\&gwh=44F44A3665FC2D72A688A4A30BD34 0A1\&gwt=pay\&assetType=nyt_now (accessed: 27.03.2018).

31. White, J. B. (2017), Republican accuses Russia of interfering in US energy market. The Independent, September 28, available at: https://www.independent.co.uk/news/world/americas/us-politics/russia-google-facebook-interference-energy-market-fracking-adverts-a7970936.html (accessed: 27.03.2018).

32. Tsvetkova, N. (2019), Russian Digital Diplomacy: A Rising Cyber Soft Power? Velikaya A., Simons G. (eds). Russia's Public Diplomacy: Evolution and Practice. Palgrave Macmillan, London, New York, pp. 103-117.

33. House of Representatives Committee on Science, Space and Technology released a Majority Staff Report "Russian Attempts to Influence US Domestic Energy Markets by Exploiting Social Media" (2018), March 1, available at: https://www.hsdl.org/?abstract\&did=808676 (accessed: 19.03.2018).

34. Transcript of Robert S. Mueller III's testimony before the House of Representative Permanent Select Intelligence Committee (2019), The Washington Post, July 24, available at: https://www.washingtonpost.com/politics/transcript-of-robert-s-mueller-iiis-testimony-before-the-house-intelligence-committee/2019/07/24/f424acf0-ad97-11e9-a0c9-6d2d7818f3da_story.html (accessed: 25.07.2019).

Received: August 28, 2019

Accepted: October 3, 2019

Author's information:

Grigory O. Yarygin — PhD in Political Science, Associate Professor; g.yarygin@spbu.ru 